\title{
Ekranisasi Novel Hanum \& Rangga: Faith \& The City
}

\section{Lisma Meilia Wijayanti ${ }^{a, 1}$, Bambang Eko Hari Cahyono ${ }^{a, 2}$, dan Lulus Irawati $^{\mathrm{a}, 3}$}

${ }^{a}$ Universitas PGRI Madiun, Indonesia

${ }^{1}$ lismamei@gmail.com; ${ }^{2}$ behc@ unipma.ac.id $;{ }^{3}$ lulusirawati@unipma.ac.id

\section{Article info}

Article history:

Received: $26-02-2020$

Revised : 28-09-2020

Accepted: 15-11-2020

Keywords:

ecranization

Faith \& The City film

Hanum \& Rangga novel

A B S T R A C T

The ecranization process allows for change. With this change, generally, the audience will compare between the two. Thus, the audience's appreciation and even the novelist of a film often create satisfaction or vice versa. The purpose of this research is to describe and explain the expansion of the novel Hanum \& Rangga: Faith \& The City into the film Hanum \& Rangga: Faith \& The City in terms of plot. This type of research used in this research is qualitative with a qualitative descriptive method. From the results of the expansion analysis, it was found 46 shrinkage findings, 30 additional findings, and 43 varied findings. Thus, the theory of ecranization proves that the storyline of a film that departs from the novel will not be the same.

Proses ekranisasi memungkingkan adanya perubahan. Dengan adanya perubahan tersebut, umumnya penonton akan membandingkan antara keduanya. Maka, apresiasi penonton bahkan penulis novel dari sebuah film seringkali menimbulkan kepuasan atau justru sebaliknya. Tujuan penelitian ini adalah untuk mendeskripsikan dan menjelaskan ekranisasi novel Hanum \& Rangga: Faith \& The City ke dalam film Hanum \& Rangga: Faith \& The City dari segi alur. Jenis penelitian yang digunakan dalam penelitian ini adalah kualitatif dengan metode deskriptif kualitatif. Dari hasil analisis ekranisasi ditemukan 46 temuan penciutan, 30 temuan penambahan, dan 43 temuan perubahan bervariasi. Dengan demikian, teori ekranisasi membuktikan bahwa alur cerita sebuah film yang berangkat dari novel tidak akan sama persis.

Copyright () 2020 Institut Agama Islam Negeri Syekh Nurjati Cirebon. All rights reserved.

\section{PENDAHULUAN}

Novel diangkat ke layar lebar merupakan film yang sukses memikat masyarakat dari segi apresiasi maupun total jumlah penonton. Perubahan karya sastra khususnya novel menjadi film tersebut telah lama terjadi di Indonesia. Perkembangan karya sastra saat ini tidak hanya dinikmati dalam bentuk yang sama, namun juga dapat berubah bentuk atau wahananya atau dapat disebut ekranisasi dalam istilah sastra. Berbicara mengenai ekranisasi, maka alih wahana adalah sumber utama dari ekranisasi. Faidah (2019) mengungkapkan bahwa pada dasarnya terjadi peralihan dari satu wahana ke wahana yang lain. Seperti contoh dari wahana tulis ke wahana visual. Alih wahana merupakan sebuah peralihan bentuk suatu karya ke bentuk karya yang lain, sedangkan ekranisasi dikhususkan pada peralihan novel ke dalam bentuk film.

Alih wahana mencakup pemindahan dari satu jenis kesenian menjadi kesenian yang lain, misalnya dari novel ke tari, puisi ke cerpen, atau novel ke 
film. Kegiatan tersebut biasanya disebut alih wahana. Sebuah teks sastra ataupun teks drama, bila diadaptasi ke dalam bentuk film akan muncul persoalan utama yang bersumber dari kenyataan bahwa sebuah karya yang diadaptasi tersebut merupakan karya yang menarik. Artinya, karya tersebut sudah banyak mendapat simpati dari khalayak. Oleh karena itu, karya tersebut memiliki banyak penggemar, sehingga ketika karya tersebut diadaptasi ke dalam bentuk film akan banyak pula yang mengharapkan film hasil adaptasi tersebut dapat sesuai dengan aslinya.

Agustina (2016) mengungkapkan bahwa transformasi atau alih wahana adalah bagian khusus dari sebuah adaptasi, sebab hal tersebut menitikberatkan pada sebuah proses perubahan wujud sebagai suatu hasil kerja. Proses perubahan karya sastra yang berangkat dari novel menjadi film atau sebaliknya, membutuhkan kreativitas dalam proses penggarapannya. Oleh sebab itu dalam proses transformasi memerlukan imajinasi sehingga tidak menutup kemungkinan terdapat beberapa perubahan ketika pentransformasian tersebut terjadi. Perubahan yang terjadi dapat dikatakan wajar, karena dalam proses transformasi terdapat beberapa faktor dan beberapa hal penting di setiap komponennya. Penciutan yang terjadi pada proses ekranisasi, sama artinya dengan apa yang dinikmati berjamjam atau bahkan berhari-hari harus diubah menjadi beberapa puluh menit saja. Artinya, novel tebal berjumlah ratusan halaman akan terpangkas ketika diangkat menjadi film. Tidak semua yang diungkapkan di dalam novel dijumpai dalam film. Biasanya sutradara terlebih dulu memilah-milah episode yang dirasa inti cerita untuk dapat ditampilkan (Juidah, 2018).

Pada sebuah proses ekranisasi sudah pasti mengalami perubahan terutama perubahan fungsi. Maghfiroh, Mariati, dan Maslikatin (2013) mengungkapkan bahwa ekranisasi merupakan perkembangan keilmuan antara teori sastra dan teknologi, yang memberikan jembatan, pencerahan pada pemikiran dan membantu mensosialisasikan karya sastra kepada masyarakat. Praharwati \& Romadhon (2017) juga berpendapat bahwa ekranisasi merupakan sebuah proses kreatif sastra yang mewarnai perjalanan sastra Indonesia. Selain itu, ekranisasi merupakan visualisasi dari bentuk tulisan yang kemudian disuguhkan kepada penikmat karya sastra, meskipun di dalamnya terdapat perubahan-perubahan. Tidak jarang banyak kegagalan pada hasil film yang diangkat dari sebuah novel karena terlalu menyimpang dari novel aslinya. Banyak penonton yang kecewa karena hal tersebut. Namun demikian kekecewaan tersebut dikategorikan wajar selama esensi atau benang merah cerita tetap sama meskipun ada yang ditambah atau dipotong (Yanti et al., 2018). Perubahan terjadi karena ada beberapa alat-alat yang digunakan berbeda, seperti halnya mengubah kata menjadi gambar atau mengubah tulisan menjadi suara. Novel adalah karya sastra berupa tulisan di dalamnya terdapat kata-kata yang dapat dinikmati dengan indera penglihatan, sedangkan film merupakan sebuah karya berupa audio visual.

Novel merupakan kreasi individu. Orang yang memiliki kreativitas, gagasan, ataupun ide, kemudian dituangkan dalam bentuk tulisan menjadi sebuah karya sastra berupa novel dapat dinikmati oleh pembaca, namun tidak demikian dengan pembuatan sebuah film. Isnaniah (2015) film merupakan hasil kerja tim, banyak campur tangan orang lain di dalamnya serta dikerjakan secara bersamasama dengan orang banyak. Keberhasilan sebuah film bisa ditentukan oleh kekompakan kinerja antar tim. Tim tersebut biasanya terdiri dari sutradara, penulis naskah, produser, juru kamera, dan para pemain. Dapat disimpulkan 
perbedaan proses pembuatan antara novel dan film adalah merujuk pada proses pembuatan.

Salah satu unsur intrinsik paling menonjol dalam karya sastra adalah alur. Dalam pembentukan sebuah plot atau alur terdapat unsur-unsur yang paling penting yakni adanya peristiwa, konflik, dan klimaks. Ernest \& Nurgiyantoro (2018) mengungkapkan bahwa peristiwa, konflik, dan klimaks merupakan unsur yang menentukan eksistensi dalam pengembangan alur cerita. Tiga alur cerita berbeda yang disajikan oleh pengarang dalam novel harus dapat disiasati ataupun dikompilasi oleh sutradara menjadi satu cerita yang utuh. Pemaparan dan pengaluran menjadi pilihan pekerja film untuk menjadi sudut penceritaan utama, sedangkan dua lainnya dilebur atau ditambahkan ke dalam jalan penceritaan. Perubahan alur cerita demi ketercapaian kebutuhan dramatisasi serta artistik dalam film, keefektifan dan durasi, kemudahan visualisasi, serta nilai adab dan budaya dalam film.

Dalam mengangkat sebuah novel menjadi film tentunya memiliki perbedaan. Seperti pada penelitian Rosie (2019), dalam hasil penelitiannya mengungkapkan bahwa agar film yang ditampilkan bisa berkembang dan bervariasi, maka harus dilakukan pemotongan maupun penambahan pada bagian-bagian tertentu sehingga terjadi perbedaan. Dengan adanya perubahan tersebut mendorong penonton untuk kritis dan kemudian akan membandingkan antara keduanya. Setelah membandingkan antara film dan novel diangkat menjadi sebuah film, respon yang timbul adalah kepuasan atau justru sebaliknya. Tidak hanya penonton, seorang penulis novel yang karyanya diangkat ke dalam film tidak jarang merasakan kekecewaan atau merasa tidak puas dengan hasil filmnya. Eneste (1991) berpendapat bahwa kekecewaan penonton adalah ketika sebuah novel yang mereka baca berbeda dengan film yang mereka tonton, banyak hal yang berbeda dari proses pengangkatan novel ke dalam film baik tokohnya ataupun jalan ceritanya tidak berbanding lurus dengan film yang mereka tonton sehingga timbul kekecewaan pada penonton.

Alfathoni (2017) mengungkapkan bahwa sebuah ekranisasi tidak seluruh aspek pasti dapat ditemukan. Seorang sutradara melakukan proses pengurangan, penambahan, ataupun perubahan yang memiliki unsur dramatik dalam alur cerita film. Para pekerja film sering dipusingkan oleh faktor durasi sehingga mereka harus berpikir sekreatif mungkin agar dapat memilih hal-hal penting yang dapat difilmkan. Sehingga, tidak jarang terdapat perbedaan khususnya pada alur cerita. Dengan alasan menyesuaikan fungsi dari media, maka antara novel dan film dianggap wajar jika mengalami perubahan. Kembali lagi pada proses kreatif harus menjadi pondasi utama dalam memproduksi film dari adaptasi sebuah novel. Proses kreatif tersebut penulis amati dari sutradara Benni Setiawan dalam mengangkat novel ke dalam film yang berjudul Hanum \& Rangga: Faith \& The City. Proses transformasi novel karya Hanum Salsabiela Rais dan Rangga Almahendra ke dalam bentuk film disutradarai oleh Benni Setiawan ini akan menjadi objek utama dalam penelitian ini.

Novel Hanum \& Rangga: Faith \& The City adalah novel yang di dalamnya memuat pengetahuan tentang islam yang ada di Amerika, selain itu dalam novel ini juga menyiratkan betapa pentingnya sebuah keputusan dan pilihan yang sama pentingnya (Rais \& Almahendra, 2018), oleh sebab itu penulis sangat tertarik untuk meneliti novel tersebut. Pemilihan novel Hanum \& Rangga: Faith \& The City dikarenakan ada beberapa alasan. Pertama, masyarakat cukup antusias dan 
merespon novel Hanum \& Rangga: Faith \& The City sehingga dicetak ulang sampai cetakan ketiga, kembali tulisan Hanum Salsabila ini diangkat ke layar lebar. Kedua, novel Hanum \& Rangga: Faith \& The City berhasil diadaptasi dan difilmkan oleh sutradara Benni Setiawan dengan judul yang sama Hanum \& Rangga: Faith \& The City. Ketiga, respon penonton yang cukup antusias, barubaru ini masyarakat merespon negatif tentang film tersebut terkait pemutaran serentaknya dikaitkan dengan kampanye sehingga muncul tanggapan yang beragam dari masyarakat.

Pada proses ekranisasi tentu terjadi perubahan baik penambahan maupun pengurangan. Perubahan pada alat yang digunakan, proses dan cara menikmati, serta cara penggarapan yang berbeda menjadi faktor utama munculnya perubahan. Armiati (2018) mengungkapkan bahwa perubahan tersebut sudah pasti akan terjadi, sehingga dengan kata lain ekranisasi dapat disebut dengan pengurangan, penambahan, serta perubahan yang di dalamnya terdapat variasi-variasi.

Pada penelitian ini akan dibahas mengenai beberapa perubahan yang terjadi ketika novel diangkat ke dalam bentuk film. Banyak faktor dan alasan yang mendasari perubahan tersebut. Dalam sudut pandang film, perubahan tersebut dapat dikategorikan penting dan memang perlu untuk dilakukan. Alasan lain karena memang perubahan wajib dilakukan selagi tidak mengubah inti atau esensi dari cerita secara keseluruhan. Penelitian ini fokus pada ekranisasi yang terdapat pada alur yang nantinya di dalam ekranisasi timbul beberapa temuan seperti penciutan, penambahan, dan perubahan bervariasi.

\section{METODE}

Pendekatan penelitian yang digunakan adalah pendekatan kualitatif dengan menggunakan metode deskriptif kualitatif. Sumber data yang digunakan dalam penelitian ini ada dua yakni novel Hanum \& Rangga: Faith \& The City yang ditulis oleh Hanum Salsabiela Rais dan suaminya Rangga Almahendra, serta film Hanum \& Rangga: Faith \& The City disutradarai oleh Benni Setiawan. Teknik pengumpulan data menggunakan teknik dokumentasi. Teknik keabsahan data yang digunakan dengan meningkatkan ketekunan, dan triangulasi. Metode analisis yang digunakan adalah metode analisis isi, peneliti mengklasifikasikan data dengan jenis atau kriteria tertentu, menggunakan lambang-lambang tertentu, serta menganalisis berdasarkan kriteria tertentu. Analisis isi yang diterapkan di dalam ekranisasi ini membuat peneliti memiliki waktu untuk melakukan analisis kapan saja dan di mana saja.

\section{HASIL DAN PEMBAHASAN}

Proses ekranisasi alur dalam novel Hanum \& Rangga: Faith \& The City ke dalam film Hanum \& Rangga: Faith \& The City memperoleh hasil dilihat dari kategorisasi aspek penciutan atau pengurangan, penambahan, serta perubahan bervariasi.

\section{Penciutan}

Jenis alur pada novel dalam penelitian ini berupa alur maju, dimana kejadian demi kejadian dijelaskan dan digambarkan secara utuh, rinci dan bertahap. Hal itu dimulai ketika peristiwa Hanum dan Rangga bersama Azima dan Brown menghadapi para wartawan, bertemu dengan Iqbal Fareed dan Zuraida, mendapatkan kesempatan bekerja di GNTV hingga akhirnya tokoh utama harus bergelut dengan dua pilihan antara karir dan keluarga, hingga pada akhirnya 
memutuskan untuk memilih keluarga. Hal tersebut berbeda ketika diubah dan diangkat menjadi film, alurnya berubah menjadi alur ganda yakni maju mundur. Hal tersebut dimulai ketika Azima menceritakan pengalaman kelamnya bersama sang suami dalam buku album yang ia tunjukkan kepada Hanum dan Rangga, mengiyakan tawaran GNTV, bergelut dengan pilihan hingga akhirnya memilih kembali ke pelukan Rangga. Maka terlihat jelas bahwa ekranisasi membuat adanya perubahan.

Pada hasil penelitian temuan alur penciutan terdapat 46 temuan. Data tersebut terkumpul berdasarkan temuan peristiwa sebanyak 35 temuan, konflik sebanyak lima temuan, dan klimaks sebanyak enam temuan. Berikut beberapa kutipan alur penting yang mengalami ekranisasi dari segi penciutan.

Tivy yang juga merupakan tim riset insights muslim menyodorkan Hanum sebuah nama: Iqbal Fareed. Ini adalah tugas pertama Hanum dan Sam (hlm. 50 )

Kutipan di atas adalah sebuah situasi dalam novel saat Hanum mendapati tugas pertama magang untuk mewawancarai Iqbal Fareed dan Zuraida. Dari mendapat tugas sampai dengan bertugas wawancara situasi tersebut tidak ditemukan dalam film, seperti saat wawancara dengan Iqbal Fareed berikut.

“...dua tahun lalu, stroke merenggut sebagian fungsi otaknya. Dua kali dalam setahun. Terakhir bulan lalu, namun ia tetap berketetapan hati dalam imannya yang kuat. Itulah mengapa aku memanggilnya Faith" jelas Iqbal. (hlm. 53).

Kutipan di atas adalah situasi saat Hanum dan Sam bertamu ke rumah Iqbal Fareed kemudian mereka melakukan wawancara terhadap Iqbal Fareed mengenai kisah hidup bersama isterinya. Di dalam film konteks tersebut sama sekali tidak dimunculkan, padahal situasi tersebut menurut peneliti dapat menjadi alasan mengapa judul novel tersebut menggunakan istilah "Faith" yakni dengan menganalogikan sosok Zuraida yang lemah namun tetap memiliki ketekunan hati meskipun diuji dengan penyakit dan penderitaan selama dua tahun ia alami.

Misi utama Hanum adalah menjadi jurnalis yang mampu membawa nama agamanya yakni Islam lebih baik di mata dunia, salah satunya di negara yang ia sekarang tinggali. Muncul beberapa peristiwa penting yang tidak dimuat dalam film seperti pada kutipan berikut.

Alex Reeds, anak Rhonda Reeds, mengunggah video "my friend is a bad muslim" di youtube dan juga telah ditonton ratusan ribu orang. (hlm. 136)

Konteks di atas adalah ketika Alex Reeds mengunggah video berjudul " $M y$ Friends Is A Bad Muslim" dimana tokoh Alex mengunggah video yang menunjukkan sisi negatif dari islam, dia beranggapan bahwa islam adalah agama yang tidak baik. Ia mengalami konflik dengan ibunya yang memiliki suami seorang muslim. Namun situasi tersebut tidak dimunculkan dalam film.

Pada bagian akhir, salah satu alur penting yang juga tidak ditampilkan adalah saat Hanum dihadapkan pada sebuah pilihan antara keluarga dan karirnya. Kala itu Hanum menyadari bahwa ambisi yang selama ini ia penuhi adalah keliru, 
sehingga memutuskan untuk kembali bersama Rangga. Seperti pada kutipan berikut.

"sreeeeett!" kertas kontrak yang sangat berharga itu dirobek Hanum pelan (hlm. 205)

Sebelumya terdapat konflik internal dalam jiwa Hanum dimana ia sadar bahwa selama ini Hanum salah memilih pekerjaan dan melupakan suaminya sehingga dengan emosi tersebut puncaknya Hanum merobek impiannya yang dulu sangat ingin capai yakni surat kontrak kerja. Namun, situasi tersebut tidak ditemukan dalam film.

\section{Penambahan}

Pada hasil penelitian, alur penambahan terdapat 30 temuan. Data tersebut terkumpul berdasarkan peristiwa sebanyak 26 temuan, konflik sebanyak dua temuan, dan klimaks sebanyak dua temuan.

"Isi album ini, dimulai dari tragedi terkelam keluarga kami saat suamiku dituduh sebagai teroris sampai kalian datang dan mengungkap kebenaran..." (00:00:43)

Kutipan di atas adalah kutipan di awal film ketika Azima menceritakan pengalaman kelam keluarganya melalui buku album kepada Rangga dan Hanum. Jika dicermati, konteks tersebut tidak ditemukan di dalam novel.

"Mau bicara apa lagi mas, nih foto-foto ini, pergunjingan di apartemen, Sarah cuma alasan saja kan supaya kamu bisa deket, satu paket" (00:49:02)

Kutipan di atas adalah adegan saat Hanum ingin menemui Azima tiba-tiba mendapat kiriman pesan dari The Iis yang isinya adalah foto Rangga bersama Sarah dan saat itu tidak sengaja pula memergoki Rangga di rumah Azima sehingga Hanum sangat terkejut melihat hal itu, kemudian terjadilah adegan kejarmengejar. Dalam novel situasi tersebut tidak ada dan sutradara sengaja memunculkan situasi tersebut sebagai alur tambahan.

Pada klimaks terdapat adegan Hanum secara live bersama Azima dan Brown, ketiganya kompak mempermalukan Andy di depan layar televisi. Seperti pada kutipan berikut:

"Anda siapa anda bukan siapa-siapa di GNTV // ya, awalnya iya tapi dua tahun lalu saya membeli 70\% saham di GNTV dan kebijakan saya tidak akan membiarkan pengacau dunia seperti kamu di perusahaan ini" (01:15:00)

Kutipan di atas adalah adegan saat Andy mengancam Hanum untuk menyudahi livenya, namun Andy semakin dipermalukan hingga kemudian Andy berjalan mundur keluar dari ruangan studio.

Di akhir film terdapat situasi saat Rangga datang menemui Hanum di lapangan dan menjelaskan alasannya untuk tetap tinggal menemui Hanum. Seperti pada kutipan berikut:

"Bukannya kamu udah terbang // Aku gabisa terbang kalau satu sayap aku ada yang tertinggal” (01:18:29) 
Rangga datang menemui Hanum di sebuah lapangan dekat sungai, namun dalam novel situasi tersebut tidak ada. Hanum tidak menemui Rangga ataupun menjelaskan alasannya untuk tetap tinggal. Dalam hal ini, situasi tersebut tidak ada dalam novel. Artinya sutradara sengaja menambah situasi tersebut.

\section{Perubahan Bervariasi}

Pada hasil penelitian temuan alur perubahan bervariasi terdapat 43 temuan. Data tersebut terkumpul berdasarkan temuan peristiwa sebanyak 26 temuan, konflik sebanyak 10 temuan, dan klimaks sebanyak tujuh temuan. Beberapa temuan yang paling menonjol adalah seperti pada kutipan berikut:

"aku memerlukan seorang reporter baru untuk mengisi acara baruku” Cooper dengan keelokan gayanya memberi sinyal agar mereka berdua keluar antrean. (hlm. 25)

Di dalam novel terlihat situasi saat Andy Cooper mendatangi Hanum dan Rangga di bandara JFK untuk menawarkan pekerjaan. Namun berbeda ketika dilihat pada film seperti pada kutipan berikut:

"Hay aku Samuel, nice to meet you how are you, im Samanta from GNTV..."(00:06:39)

Di dalam film, Sam mendatangi Hanum dan Rangga di apartemen kemudian Andy menelepon Hanum melalui gawai Sam untuk menawarkan pekerjaan. Dapat dilihat dalam hal ini yang berubah adalah tokohnya. Jika di dalam novel Andy yang datang menemui Hanum dan Rangga untuk menawari pekerjaan, namun di dalam film Samlah yang datang menemui Hanum dan Rangga untuk menawari pekerjaan.

Perubahan berikutnya adalah situasi dalam novel saat Zakiyah meminta Hanum untuk mematikan kamera saat Yahya menangis. Seperti pada kutipan berikut:

"Tolong Hanum, katakan pada juru kameramu. Berhenti merekam.

Kita sama-sama muslim, kan...” (hlm. 80)

Sementara dalam film Zakiyah meminta Sam untuk mematikan kamera saat Yahya menangis, kemudian baru Hanum yang meminta kepada John.

"Stop recording plis Sam!" (00:25:57)

Dari kutipan novel dan film di atas sangat jelas menunjukkan perbedaan. Terlihat Zakiyah langsung meminta tolong kepada Sam untuk mematikan kameranya yang menyala.

Perubahan lainnya adalah saat awal mula konflik Hanum dan Rangga, ketika Hanum berbohong kepada Rangga seperti pada kutipan berikut. "aku tadi mau mengajakmu makan malam. Layla Brown memberiku rekomendasi restoran romantis. Tapi sudahlah kalau kau masih liputan" (hlm. 91)

Kutipan di atas adalah situasi dalam novel saat Rangga menelepon Hanum untuk mengajak makan malam, namun Hanum menolak dengan alasan sedang liputan. Di dalam film situasinya berubah yakni Rangga menelepon Hanum untuk mengajak makan siang, namun Hanum menolak dengan alasan sedang meeting, seperti pada kutipan berikut: 
"aku mau ngajak kamu lunch ni sekarang yuk // sebenarnya aku lagi ada meeting sekarang aku gabisa deh kayaknya" (00:42:57)

Perubahan pada posisi Rangga jika pada novel melihat Hanum yang berbohong ketika diajak makan siang dengan alasan meeting, namun Rangga melihat bahwa Hanum sedang duduk termenung di GNTV, kemudian pada film Rangga memergoki Hanum dan Andy berjalan keluar dari gedung GNTV menuju tempat makan dan tidak sedang meeting.

Di akhir cerita terdapat situasi saat di bandara JFK, Hanum berjanji kepada Rangga untuk melunasi hutangnya menemani Rangga menyelesaikan pening disertasinya.

"aku ingin melunasi utangku yang lain, mas Rangga. Utang janjiku untuk menyelesaikan PENING DISERTASI-mu dengan Reinhard. Aku enggak pernah bohong kan?" (hlm. 208)

Sedangkan dalam film situasi tersebut terjadi di sebuah lapangan, dimana Hanum berjanji kepada Rangga untuk melunasi hutangnya menemani Rangga menyelesaikan pening disertasinya.

"Sekarang kemanapun kamu pergi aku janji akan terus ngikutin kamu Mas” (01:18:50)

Dari beberapa kutipan tersebut menunjukkan adanya perubahan bervariasi pada alur novel ke film Hanum \& Rangga: Faith \& The City.

Dari beberapa kutipan temuan di atas, maka peneliti memperoleh hasil penelitian ekranisasi dari segi alur secara keseluruhan terdapat 120 temuan. Temuan tersebut sudah berdasarkan pengelompokan ekranisasi yakni penciutan atau pengurangan, penambahan, serta perubahan bervariasi. Pada hasil penelitian temuan alur penciutan terdapat 46 temuan. Data tersebut terkumpul berdasarkan temuan peristiwa sebanyak 35 temuan, konflik sebanyak lima temuan, dan klimaks sebanyak 6 temuan. Pada hasil temuan alur penambahan terdapat 30 temuan. Data tersebut terkumpul berdasarkan temuan peristiwa sebanyak 26 temuan, konflik sebanyak dua temuan, dan klimaks sebanyak dua temuan. Pada hasil penelitian temuan alur perubahan bervariasi terdapat 43 temuan. Data tersebut terkumpul berdasarkan temuan peristiwa sebanyak 26 temuan, konflik sebanyak 10 temuan, dan klimaks sebanyak tujuh temuan.

Dalam penelitian ini banyak beberapa pengurangan dan perubahan yang ditemukan. Seperti pada hasil penelitian milik Fajrin (2016) bahwa prolog dalam novel berbeda dengan prolog dalam film. Begitu juga dengan penelitian ini. Prolog dalam novel menceritakan peristiwa wawancara antara wartawan dengan Azima dan Brown yang didampingi oleh Hanum Rangga, keadaan tersebut dideskripsikan dalam keadaan ricuh. Sementara dalam film, prolog menggambarkan keadaan santai saat Azima menceritakan pengalaman hidupnya kepada Hanum dan Rangga. Inda (2016) dalam penelitiannya menegaskan bahwa dalam proses pengangkatan novel ke dalam film tidak seluruhnya dapat dimunculkan, sehingga terjadilah pemangkasan terhadap beberapa bagian novel. Salah satu yang paling menonjol adalah alur Iqbal Fareed dan Zuraida yang secara tidak langsung keberadaanya dalam novel sangat menjawab alasan pembaca tentang arti 
judul "Faith", yakni sosok Zuraida yang lama menderita sakit lumpuh namun ketetapan hatinya sebagai muslim tetap ia junjung tinggi meskipun diuji dengan cobaan yang berat, itulah alasan mengapa Iqbaal Fareed memanggil istrinya dengan sebutan "Faith".

Penambahan alur ketika The Iis tidak sengaja mengirimkan foto Rangga dan Azima kepada Hanum sehingga memunculkan konflik baru. Penambahan alur tersebut selain untuk memperkuat konflik pada inti cerita juga bertujuan untuk memunculkan koflik baru yang klimaksnya adalah inti cerita tersebut sehingga membuat cerita lebih menarik (Ardianti \& Widayati, 2018). Perubahan alur saat Rangga menelpon Hanum untuk mengajak makan malam dan kemudian ditolak karena meeting hingga klimaksnya Rangga memergoki Hanum sedang duduk termenung, alur tersebut berubah dalam film yakni Rangga menelepon Hanum untuk mengajak makan siang kemudian ditolak karena meeting, sehingga klimaksnya Rangga memergoki Hanum sedang berjalan keluar dari gedung GNTV dengan Andy. Hal tersebut sejalan dengan penelitian milik Anam \& Saksono (2017) pada hasil penelitiannya menunjukkan bahwa perbedaan konflik yang terjadi antara novel dan film terletak pada penggambaran karakter tokoh meskipun karakter yang dimiliki tokoh tetap sama.

Hasil penelitian ini sejalan dengan penelitian oleh Rizki (2017) dikatakan sejalan karena temuan penelitian lengkap, artinya ketiga proses ekranisasi yakni penambahan, pengurangan, dan perubahan terjadi pada penelitian. Hal ini menunjukkan bahwa proses ekranisasi dalam mengangkat sebuah novel ke dalam layar lebar terbukti adanya perubahan. Hasil penelitian ini sejalan dengan penelitian Nur \& Ricahyono (2019) karena ekranisasi alur yang ditemukan lengkap dengan memuat aspek pengurangan dalam ekranisasi, penambahan dalam ekranisasi, dan perubahan dalam ekranisasi.

Hasil penelitian ini juga sejalan dengan penelitian Mariati (2011) yang menyatakan bahwa bahwa pengurangan cerita yang dilakukan atas dasar menyesuaikan dengan waktu atau film yang sangat terbatas. Artinya, banyak bagian peristiwa di dalam novel yang sengaja dihilangkan dalam film. Hal tersebut karena menyesuaikan durasi film menjadi alasan utama. Hal tersebut diperkuat dengan penelitian Rizki \& Kusuma (2018) dalam temuan penelitiannya mengatakan bahwa secara keseluruhan pengurangan tokoh, latar, dan alur yang terjadi dari novel ke film dikarenakan tidak begitu penting sehingga ditiadakan. Dengan kata lain, dalam proses ekranisasi pasti terdapat perubahan. Fadilla et al., (2018) mengungkapkan bahwa banyak faktor penyebab perubahan tersebut. Alat yang digunakan menjadi faktor utama penyebab perbedaan tersebut. Penulis dan sutradara tentunya memiliki alasan tersendiri untuk memilih bagian-bagian yang sengaja dipotong atau ditambah entah dari segi durasi maupun selera kenikmatan penonton secara umum.

Secara keseluruhan proses penelitian ekranisasi ini berdasarkan tiga aspek transformasi menyebabkan perubahan terhadap alur. Pertama, pengurangan plot atau alur dikarenakan durasi untuk mengoptimalkan film agar tidak terlalu panjang atau pendek sehingga banyak alur yang dipotong. Kedua, aspek penambahan alur terjadi pada terlalu fokus tujuan, alur seperti ini dikarenakan film ini difokuskan kepada orang-orang yang sudah membaca sehingga tidak masalah untuk menambahnya agar menarik. Ketiga, aspek perubahan variasi 
terjadi karena alat yang digunakan pada film berbeda dengan alat yang digunakan pada novel. Namun perubahan ini masih dikatakan wajar karena tidak berbeda jauh dengan peristiwa-peristiwa alur yang ditampilkan dalam novel.

\section{SIMPULAN}

Berdasarkan hasil penelitian dan pembahasan ditemukan ekranisasi dari segi alur secara keseluruhan terdapat 120 temuan. Pada hasil penelitian temuan alur penciutan 46 temuan, penambahan 30 temuan, dan perubahan bervariasi 43 temuan. Pada teknik penceritaan mengalami perubahan dari alur maju menjadi alur maju mundur. Ketiga aspek ekranisasi dapat ditemukan, meskipun sangat disayangkan ada beberapa peristiwa alur tidak dimunculkan dalam film. Meskipun demikian tidak mengubah esensi dari cerita. Hasil temuan berupa penciutan dalam ekranisasi, penambahan dalam ekranisasi, dan perubahan dalam ekranisasi. Penelitian ekranisasi pada alur ini dapat digunakan sebagai rujukan dan bahan pertimbangan pada penelitian selanjutnya di bidang sastra khususnya penelitian ekranisasi. Kendala yang dihadapi dalam proses analisis ini sulit menggali data dari narasumber yaitu penulis novel ataupun sutradara film. Dengan demikian untuk penelitian selanjutnya dapat menggunakan metode wawancara dengan penulis ataupun sutradara sehingga data yang dikumpulkan lebih akurat.

\section{DAFTAR PUSTAKA}

Agustina, A. (2016). Transformasi Naskah Lakon Macbeth (1603-1607) Karya William Shakespeare Ke Film Throne of Blood atau Kumonosu-Jo (1957) Karya Akira Kurosawa. Journal of Urban Society's Arts, 3(1), 1-9.

Anam, M. A. A., \& Saksono, L. (2017). Kajian Ekranisasi Dongeng Die Goldene Gans Karya Brüder Grimm Dengan Film Die Goldene Gans Karya Carsten Fiebler. Identitaet, 5(1), 1-5.

Ardianti, E. R., \& Widayati, S. (2018). Ekranisasi Cerpen Filosofi Kopi Karya Dewi Lestari (DEE) Ke Dalam Film Filosofi Kopi Sutradara Angga Dwimas Sasongko sebagai Alternatif Bahan Ajar di Sekolah Menengah Atas. Elsa, 16(2), 1-13.

Armiati, Y. (2018). Ekranisasi Novel Assalamualaikum Beijing Ke Dalam Film Assalamualaikum Beijing. Master Bahasa, 6(3), 301-310.

Eneste, P. (1991). Novel dan Film. Nusa Indah.

Ernest, Y. K., \& Nurgiyantoro, B. (2018). Kajian Ekranisasi: Dari Novel Pintu Terlarang Ke Film Pintu Terlarang. Diksi, 26(2), 120-127.

Fadilla, S., Juned, S., \& Nursyirwan. (2018). Ekranisasi Novel Ke Film Surga Yang Tak Dirindukan 2 Dengan Kajian Interteks. Widyaparwa Institut Seni Indonesia Padangpanjang, Indonesia, 46(2), 220-230.

Faidah, C. N. (2019). Ekranisasi Sastra sebagai Bentuk Apresiasi Sastra Penikmat Alih Wahana. Hasta Wiyata, 2(2), 1-13.

Fajrin, H. (2016). Ekranisasi Novel Ke Film Surga Yang Tak Dirindukan ( Ecranisation of Surga yang Tak Dirindukan Novel to Film ). Sawerigading, 22(1), 73-82.

Inda, N. D. (2016). Adaptasi Novel Ronggeng Dukuh Paruk Ke Dalam Film Sang Penari: Sebuah Kajian Ekranisasi. Aksara, 28(1), 25-38.

Isnaniah, S. (2015). Ketika Cinta Bertasbih Transformasi Novel Ke Film. Kawistara, 5(1), 23-35.

Juidah, I. (2018). Transformasi Novel Cinta Suci Zahrana Karya Habiburrahman 
El Shirazy Menjadi Bentuk Film Cinta Suci Zahrana: Sebuah Kajian Ekranisasi. Bahtera Indonesia, 3(2), 45-53.

Maghfiroh, L., Mariati, S., \& Maslikatin, T. (2013). Ekranisasi Cerpen “ Jendela Rara " Ke Film Rumah Tanpa Jendela: Kajian Psikologi Anak Analysis Ecranisation “Jendela Rara ” Short Story To Film Rumah Tanpa Jendela : Child Of Psychology. Publika Budaya, 1(1), 1-10.

Mariati, S. (2011). Perempuan Berkalung Sorban: Kajian Ekranisasi. Semiotika, 12(2), 117-124.

Nur, W., \& Ricahyono, S. (2019). Kajian Ekranisasi Novel “ Assalamualaikum Beijing " Karya Asma Nadia dalam Bentuk Film " Assalamualaikum Beijing " Sutradara Guntur Soeharjanto. Linguista, 3(2), 69-79.

Praharwati, D. W., \& Romadhon, S. (2017). Ekranisasi Sastra: Apresiasi Penikmat Sastra Alih Wahana. Buletin Al-Turas, 23(2), 267-286.

Rais, H. S., \& Almahendra, R. (2018). Hanum \& Rangga: Faith \& The City. Gramedia Pustaka Utama.

Rizki D, D. (2017). Proses Adaptasi (Ekranisasi) Novel “Tenggelamnya Kapal Van Der Wijck" Karya Hamka. Layar: Jurnal Ilmiah Seni Media Rekam, 4(1), Abstrak.

Rizki, G., \& Kusuma, A. W. (2018). Ekranisasi Novel ke Bentuk Film Dear Nathan Karya Erisca Febriani: Teori Pamusuk Eneste. Prosiding Seminar Nasional Bahasa dan Sastra SENABASTRA X, 45-51.

Rosie, F. M. D. (2019). Ekranisasi Novel Air Mata Tuhan Karya Aguk Irawan Mn Ke Dalam Film Air Mata Tuhan Karya Hestu Saputra. Journal of Chemical Information and Modeling, 53(9), 1689-1699.

Yanti, P. G., Hidayatullah, S., \& Khairani, R. (2018). Representasi Ekranisasi Novel Dear Nathan Karya Erisca Febriani. Imajeri: Jurnal Pendidikan Bahasa dan Sastra Indonesia, 01(1), 45-50. 